about 30 senior administrators convened two weeks ago by Gibbons and Bowman Cutter of the National Economic Council. The so-called deputies' science and technology working group was asked to nominate people within their agencies to serve on panels that will develop policies for 15 topics ranging from specific issues such as medical technology to basic research itself. The goal of the group, according to Tim Newell of OSTP, is to propose specific ways to carry out the president's technology initiative announced in February, but the group is also expected to make recommendations for programmes to be included in the budget for fiscal year 1995 that will be submitted to Congress next winter.

Part of the reason for the uncertainty surrounding the new administration's plans for science are the large number of unfilled positions at OSTP and the ambiguous relationship between it and the office of Vice President $\mathrm{Al}$ Gore, the leading figure within the administration on technology issues. Gibbons is believed to be planning a realignment of portfolios, elevating the environment and lowering the life sciences in the OSTP hierarchy, but only one of his choices for the four vacant associate directorships has as yet been cleared by the White House and nominated by the president.

Jeffrey Mervis

\section{Britain backs down over threat to run universities}

London. The British government has backed down under pressure from the House of Lords over a controversial proposal that would have given the Secretary of State for Education formal responsibility for the way in which universities are run (see Nature 362, 275; 1993).

The government had argued that its proposal to include words expressing the minister's responsibility for further and higher education in a new bill would have had little impact, because the main thrust of the bill in question was changes in the administration of schools. However in a parliamentary debate last week, members of the House of Lords, reflecting concerns expressed by many university vice-chancellors, claimed that the offending clause could be used to justify direct intervention by the government in university administration - and was, as such, an infringement on academic freedom.

Baroness Blatch, minister of state in the Department for Education, announced that the government had agreed to withdraw its proposal and that she would seek discussions with its critics on a more acceptable formulation of the secretary of state's responsibilities.

David Dickson

\title{
Choice to head NIST defines shift in US technology policy
}

San Francisco \& Washington. The nomination of Arati Prabhakar as director of the US National Institutes of Standards and Technology (NIST) clearly shows the contrast between the views of President Bill Clinton and former President George Bush on industrial policy.

Three years ago, Craig Fields was forced out as director of the Defense Advanced Research Projects Agency (DARPA) after Prabhakar, then deputy director of DARPA's defence sciences office, made a $\$ 4$ million investment in Gazelle Microcircuits Inc., a tiny Silicon Valley semiconductor company that makes high-speed gallium arsenide chips. The agreement angered the Bush administration, which was philosophically opposed to the government becoming a venture capitalist for fledgling companies. Although the government eventually decided to accept royalties from sales of the chip rather than to take an equity share in the company, it was widely seen as the last straw in a conflict between Fields and the administration.

Now Prabhakar, a 34-year-old applied physicist, is poised to become head of NIST, to which the Clinton administration has given a leading role in stimulating the US economy. Not surprisingly, her former boss is delighted by her promotion.

"She is a very, very capable manager", says Fields, chief executive officer of the industry-led Microelectronics Computer Consortium in Austin, Texas. "She's innovative and she understands new technology and how to apply it."

Although Gazelle's technology was impressive, the company was unable to survive on its own. In 1991, a year after the Pentagon's investment, Gazelle merged with two other chip makers, TriQuint Semiconductor of Beaverton, Oregon, and GigaBit Logic of Newbury Park, California. TriQuint had been making the chips designed by Gazelle's researchers, and its name was retained by the new company, which last year had a turnover of about $\$ 30$ million and showed a small profit.

The US government continues to receive royalties from the sale of chips designed under the original agreement with Gazelle, although TriQuint is no longer receiving any support from ARPA (the ' $D$ ' was dropped last month as part of the Clinton administration's promise to shift spending from the military to the civilian sectors). Spencer Brown, TriQuint's executive vice president and chief financial officer, says that the federal contribution enabled Gazelle to continue improving its technology and that the company expects increased demand for its products if a national information superhighway becomes a reality (see Nature 362, 582; 1993).

Fields is confident that Prabhakar, who now directs ARPA's \$300-million microelectronics technology office, can run an agency whose budget is expected to quadruple to $\$ 1.4$ billion in the next four years. But he warns his former coworker that her every move will be scrutinized.

"If one tries to help every industry, you spread yourself too thin", says Fields. "But if you favor those with the best chance of succeeding, then you leave yourself open to political attacks from those left out."

The Clinton administration hopes to prevent that from happening. Speaking last week at a conference entitled "New Directions in Technology Policy", Commerce secretary Ron Brown said that "a raging debate about the proper relationship between industry and the government" is over and that the government is "ready to work hand-in-hand with industry to strengthen the US economy". If nothing else, Prabhakar's appointment seems to be proof of that commitment.

Frederic Golden \& Jeffrey Mervis

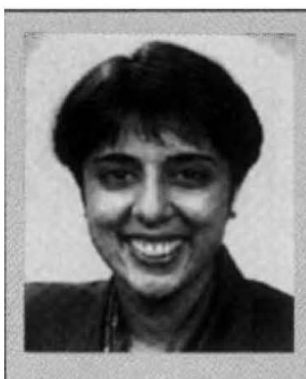

Arati Prabhakar was born in India and moved to the United States at the age of 3 . Trained as an electrical engineer she received her $\mathrm{PhD}$ in applied physics from

California Institute of Technology in Pasadena and moved to Washington in 1984 to become a congressional fellow at the Office of Technology Assessment.

In 1986 she joined the Defense Advanced Research Projects Agency (DARPA), first as programme manager of the electronics sciences division of the Defense Sciences Office and, later as deputy director of the office, where she negotiated the agreement with Gazelle (see left). Two years ago, she was asked to head a new office on microelectronics technology, with an annual budget of $\$ 300$ million.

Although Prabhakar has declined to talk to the media until after she is confirmed by the US Senate, three years ago she described her job at DARPA as one of "making sure that things happen. My goal is to get the technology out of the lab and into the hands of others." That statement is also an apt description of what she will be asked to do at NIST.

F.G. \& J.M. 